\title{
Asian Inheritors of a Western Legacy?
}

\begin{abstract}
While we must recognize the incredible contributions the West has made to global institutions, especially the United States, the increased influence of Asian nations, in particular China, gives them the opportunity to inherit and reform classic institutions of the current world order for a new era.
\end{abstract}

Q: The world has suffered from the Covid-19 pandemic in the past year. Against this backdrop, how do you see international relations in the present and in the future?

Covid-19 has had a massive impact on humanity. It spread rapidly to every corner of the world. It has also paralyzed globalization in significant ways. Equally importantly, Covid-19 is posing a question to humanity: is the human species still the smartest species on planet earth?

If it was, the human species should quickly learn the main lesson from Covid-19: all of humanity is now on the same boat. As I documented in "The Great Convergence" (translated into Chinese) before modern globalization, when humanity lived in 193 separate countries, it was also living in 193 separate boats. Covid-19 has reinforced the message that we no longer live in 193 separate boats. Instead, we live in 193 separate cabins on the same boat.

Even though all of humanity now lives on the same boat, contemporary international relations, both in theory and practice, continue to pretend that we live in separate boats. This has, in turn, prevented humanity from cooperating effectively to deal with Covid-19, global warming, and other pressing global challenges.

The time has therefore come for Western scholars to significantly revise their theories and practices of international relations. They should understand and accept the main message of Covid-19: all of humanity now belongs to one community with a shared future.

Originally published in People's Daily, April 6, 2021 


\section{Q: You stated several times that the world was a "global village" and "we are all in the same boat". In this "global village", how do you evaluate the significance of multilateralism and free trade?}

Since all of humanity now lives in the same boat, it would be suicidal for us to only take care of our cabins only. We also have to take care of the boat as a whole because if the boat sinks, our cabins will sink.

Covid-19 reinforced this message. When the global economy shrank as a result of Covid-19, all economies around the world suffered, proving again that we are on the same boat.

Against this backdrop, we should be truly grateful that the Western countries, led by the US and Europe, established the UN multilateral system in 1945. It's not a perfect system. However, despite all its defects, it has worked well. It has prevented World War III. This is why it was a huge mistake for the US (with the compliant support of some European countries) to progressively weaken the UN multilateral system, especially by depriving it of funding.

Fortunately, some wise American leaders, including Bill Clinton, have advised their fellow Americans to strengthen, not weaken, the UN multilateral system. In 2003, Bill Clinton said that the US "should be trying to create a world with rules and partnerships and habits of behavior that we would like to live in when we're no longer the military, political, economic superpower in the world."

Since President Joe Biden comes from the same party as Bill Clinton, he should heed this wise advice and strengthen multilateralism. President Biden has made a good start by returning to the WHO and the Paris Climate Accords.

\section{Q: You said in a Público interview that China has no aspirations for world leadership. How do you view China's acts and its role on the world stage?}

It is wise for China not to aspire for world leadership at this stage of its development. It is no secret that the Western world, especially the US, has become deeply troubled by the rapid return of China. Hence, as I document in my book, Has China Won? (which will soon be published in China), the US will try very hard to maintain its number one position in the world. This is normal behavior for all great powers, as documented by Graham Allison, the Harvard Professor. Nonetheless, despite the opposition of the West, China should continue its policies of opening up its economy and integrating it with the rest of the world. It took great courage for China to plunge into the "choppy waters of globalization". As President Xi said in Davos in January 2017, "we have had our fair share of choking in the water and encountered whirlpools and choppy waves but we have learned how to swim in the process. It has proved to be a right strategic choice".

It is also no secret that many Western populations, including the US, have turned against globalization. This is why the US withdrew from the Trans-Pacific Partnership. By contrast, China has continued to join the Free Trade Agreements, like the Regional Comprehensive Economic Partnership. It has also indicated that it may join the Comprehensive and Progressive Agreement for Trans-Pacific Partnership (CPTPP). This is the best contribution that China can make to uplifting and improving 
the human condition: to keep its economy open and continue integrating with the world.

\section{Q: You once praised China's resilience and executive ability. Could you please explain it more specifically, especially regarding China's fight against the pandemic?}

When Covid-19 surfaced and spread around the world, it would have been more natural for the advanced and developed countries of the West, especially the US and EU members, to handle this pandemic well and competently and for the less developed countries of East Asia, including China, to handle it less well and competently. Instead, to the shock of the world, the opposite happened. The Western countries handled it incompetently, as shown their death rates per million (US: 1430, UK: 1651, Belgium: 1841, France: 1208) and East Asian countries handled it more competently, as shown in the death rates per million (Singapore: 5, Vietnam: 0.4, China: 3, South Korea: 29). Why did China handle the pandemic better than the US? The answer is complicated. However, one important reason is that the US, since the days of Ronald Reagan, has defunded, delegitimized, and demoralized key government offices (including the CDC). This happened because Ronald Reagan famously said, "Government is not the solution to our problem. Government is the problem. By contrast, China, learning from its East Asian neighbors, regenerated a culture and system of meritocracy in its government agencies. Hence, the quality of mind of government administrators in China has been going up. When I was Dean of the Lee Kuan Yew School of Public Policy, NUS from 2004 to 2017, I told the students that the best formula for any country to apply to improve its governance was to implement meritocracy, pragmatism and honesty (MPH). This MPH formula explains Singapore's extraordinary success. It is also being implemented in China. Hence, I am optimistic that the quality of governance in China will continue to improve.

\section{Q: You pointed out in a recent interview that the US now has a "government of the $1 \%$, by the $1 \%$, for the $1 \%$ ", while the Communist Party of China (CPC) wins the support of the Chinese people. Could you please share more about your understanding of CPC's style of leadership and governance?}

There is no question that the US has been one of the successful nations in human history. It is the only country to send a man to the moon. In the same period, America's middle classes prospered. Sadly, in recent years, the US has become the only major developed country where the average income of the bottom $50 \%$ has declined over a 30 year period. In part, this is a result of the US becoming a plutocracy, where the interests of the top $1 \%$ take priority over the bottom 50\%. The late Paul Volcker, former head of the Fed, Joseph Stiglitz and Martin Wolf have called the US a plutocracy. In turn, as the Nobel Laureate Angus Deaton has documented, a "sea of despair" has been created among the working classes in the US.

By contrast, in terms of human, social, and economic development, the bottom $50 \%$ in China have had their best 40 years in five thousand years of Chinese history. A Stanford University Professor says “in contrast to America's stagnation, China's culture, self-concept, and morale are being transformed at a rapid pace-mostly 
for the better". Consequently, support for the Chinese government has grown in China. A rigorous academic study of the Harvard Kennedy School of Government has documented how support for the Chinese government has gone up from $86 \%$ in 2003 to $93 \%$ in 2016. Similarly, a study by the Edelman Trust Barometer showed that of 11 countries surveyed, the country with the highest level of trust in government was China's government of $90 \%$.

\section{Q: Your latest book raised a question: Has China won? Nearly one year has passed since the book was published. What would your answer be now?}

The title of my book, Has China Won? has a question mark. It does not say that China has won. However, even though the outcome is far from certain, it does suggest that China is winning because it appears to have a comprehensive long-term strategy to manage the US-China geopolitical contest while the US, sadly, doesn't have a similar strategy, as confirmed to me personally by Henry Kissinger, America's greatest living strategic thinker (who made a historic visit to China 50 years ago)

The main goal of this book is to prevent a major tragedy from emerging in the form of an unchecked, uncontrolled geopolitical contest because the US and China. The book concludes by saying that even though a strong consensus has built up in the Washington DC establishment that the time has come for the US to stand up to China, a rational and objective analysis of the core interests of the US and China will show that there are at least five non-contradictions between the US and China. For example, if the core goal of the US government is to improve the well-being of the American people, and if the core goal of the Chinese government is to improve the well-being of the Chinese people (as it should be), there is no contradiction between American and Chinese interests here. Similarly, both US and China share common interests in dealing with common global challenges like Covid-19 and global warming. It is my sincere hope that my book, Has China Won?, will help to improve mutual understanding between the US and China.

\section{Q: You said in a recent article that "the future of Asia will be written in four letters, RCEP, and not the four letters in Quad." How will the RCEP spell the future of Asia? What role will China play?}

The reason why the future of Asia will be written in these four letters, RCEP, and not the four letters in QUAD is because the real competition will take place in the economic, not military, spheres. Indeed, it was one of the greatest strategic thinkers of the US, George Kennan, who advised his fellow Americans that they should pay greatest attention to the strength of American society, not the American military. He said: "It is rather a question of the degree to which the United States can create among the peoples of the world generally the impression of a country which knows what it wants, which is coping successfully with the problems of its internal life and with the responsibilities of a world power, and which has a spiritual vitality capable of holding its own among the major ideological currents of the time."

When Kennan spoke about the "spiritual vitality" of American society, he was not talking about the degree of religiosity of Americans, Instead, he was talking about the social and psychological health of American society. Hence, if George Kennan 
were alive today, he would heartily disapprove of the $\$ 5$ trillion the US has spent fighting unnecessary wars since 2001 while allowing a "sea of despair" to emerge among the working classes of America. He would also advise his fellow Americans to cut down the military budget, stop fighting wars (and Kennan opposed the invasion of Iraq), and spend money on improving the civilian society of the US. He would have disapproved of Trump's withdrawal from the Trans-Pacific Partnership (TPP).

The best thing both the Biden Administration can do is to find a way of improving its economic engagement with East Asia, though rejoining TPP or cooperating with RCEP, and reducing its military engagements in the region, like in QUAD. China is wise to focus on economic cooperation, through joining RCEP and thinking of joining CPTPP.

\section{Q: China is the first major economy to recover from the pandemic. How would China's economic recovery contribute to the world?}

Covid-19 did real damage to the global economy. The IMF estimates that the global economy shrank by $3.5 \%$ in 2020 . It estimates that it will grow by $5.5 \%$ in 2021 . However, for it to grow, it needs strong engines of growth.

In this regard, the world should send a thank you note to China for succeeding in achieving positive economic growth in 2020 (1.9\%) when the US and EU shrank by $(3.4 \%)$ and $(7.2 \%)$ respectively. China saved the world economy in 2020.

It will play an important role in the coming decade. One little known fact about the US and Chinese economies is that while the US economy (USD 21 trillion) is still larger than the Chinese economy (USD 14 trillion), the size of the retail goods market in China has become bigger than that of the US. In 2009 China's market was USD 1.8 trillion, while that of the US was more than twice as large at \$4 trillion. However, by 2019, China's market had grown to USD 6 trillion while that of the US only grew to USD 5.5 trillion. In the next ten years, there is no question that the retail goods market in China will grow faster than that of the US.

Countries all over the world, especially in the poor developing countries, will be looking for export markets to boost their economic growth. This is where China can play an important role. It can improve its markets faster, especially for poor developing countries. History has taught us that trade is more effective than aid in promoting economic growth and reducing poverty. The world will be truly grateful to China if it can import more from the rest of the world. 
Open Access This chapter is licensed under the terms of the Creative Commons AttributionNonCommercial-NoDerivatives 4.0 International License (http://creativecommons.org/licenses/bync-nd/4.0/), which permits any noncommercial use, sharing, distribution and reproduction in any medium or format, as long as you give appropriate credit to the original author(s) and the source, provide a link to the Creative Commons license and indicate if you modified the licensed material. You do not have permission under this license to share adapted material derived from this chapter or parts of it.

The images or other third party material in this chapter are included in the chapter's Creative Commons license, unless indicated otherwise in a credit line to the material. If material is not included in the chapter's Creative Commons license and your intended use is not permitted by statutory regulation or exceeds the permitted use, you will need to obtain permission directly from the copyright holder.

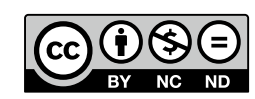

